\title{
An Empirical Evidence of Corporate Social Responsibility by Banking Sector based on Bangladesh
}

\author{
Mahjabeen Ferdous \& Md. Moniruzzaman
}

Lecturer in Finance, Department of Business Administration, Stamford University Bangladesh

\begin{abstract}
This paper present the current Corporate Social Responsibility practices by banking sector in Bangladesh. It also attempts to examine the importance of CSR (Gaining Competitive advantage, Customer's and Employee's Positive Behavior, Financial performance, etc) using open end questionnaire aims to collect respondent's opinion. Data analyzed by Statistical tool hypotheses ( $Z$ statistic-Proportion Test) along with descriptive analysis. DBBL is one of the top most banks in practicing CSR activities. The most practiced area is Education; PCB may diversify CSR practices in women empowerment, poverty alleviation as it is not enough to contribute the overall development of the country as well as other sector such as telecommunication, manufacturing industry may come forward for CSR practices.
\end{abstract}

Key Words: Corporate Social Responsibilities, Private Commercial Bank, Bangladesh

JEL Classification Code: M14

\section{INTRODUCTION}

$\mathrm{T}$ The Corporate Social Responsibility (CSR) is a blessing now a day and gradually it is achieving huge popularity among the businesses. For this reason CSR is one of the most crucial topics to the business world as well as to the government. There is an old proverb, The old proverb, "Everybody talks about society, but nobody does anything about it" is not valid in this century because Almona, C. P. (2005) alleged that the role of business worldwide and specifically in the developed economies has evolved over the last few decades from classical 'profit maximizing' approach to a social responsibly approach, where businesses are not only responsible to its stockholders but also to all of its stakeholders in a broader inclusive sense. There are many reasons behind the scenario but negative impression of stockholders on the enterprise may get preferences among others. Although the enterprise builds profit and job opportunities for the society but on the other hand, it damages the environment which impact falls on human health and nature. Now Corporate Social Responsibility (CSR) is a prime concern to the society. Banking industry now a day plays a vital role and has large contribution to the society. The economy of Bangladesh is largely dependent on banking industry. The banking division of Bangladesh includes nationalized private banks, specialized banks, private commercial banks, public commercial banks and foreign banks where there are more than thirty five private commercial banks; operating in Bangladesh. The research has focused on private commercial banks because the research topic covers CSR practices of private commercial banks in Bangladesh. Like every business organization, banking industry is very competitive.
Corporate Social Responsibility (CSR) is considered one of the most powerful weapons to acquire the competitive advantage among different competitors. CSR is now closely related with modern businesses. There are some advantages of CSR activities. To reduce risk, to get competitive advantage, to capture market share and reputation CSR is very helpful. Not only the private commercial bank are concerned with the CSR activities now a day, but also the Bangladesh Bank (The central bank of Bangladesh) is giving its strong focus to facilitate CSR in the banking industry. But still, we are falling behind in this respect comparing to developed countries of the world. Now CSR is a daily task for the private commercial banks like deposit currency, account opening, providing loan and they have gained a lot of success in this field. Every year each and every bank incurs good and big amount of money for the CSR purposes. The Bangladesh Bank (The Central Bank of Bangladesh)is now very concern about the CSR activities and various steps are already accumulated by Bangladesh Bank for the improvement of CSR activities such as encourage private commercial banks in CSR activities for this NBR issued rules on tax rebate for CSR activities. Today it is not an obligation, but a challenge too. In a word, to run the business effectively and competitively there is no alternative of CSR.

\section{ObJectives of the Study}

The objectives of this research paper are to study the CSR practices of different private commercial bank in Bangladesh. There are some specific objectives also which are given below:

- To achieve knowledge about different CSR activities of private commercial banks in Bangladesh.

- To identify the important areas where CSR activities 
are performing Bangladesh and also future prospective areas where PCB can exercise.

- To evaluate and examine the role of CSR activities of private commercial banks in Bangladesh.

\section{Literature Review}

CSR can be viewed as a comprehensive set of policies, practices, and programs that are integrated into business operations, supply chains, and decision making processes throughout the company and include responsibilities for current and past actions as well as adequate attention to future impacts. CSR focuses vary by business, by size, by sector and even by geographic region. The area of CSR is quite big and it includes all the good practices that increase the business profitability and can preserve interest of all stakeholders [1]. Ali Abbaas Albdour (2012) the early writings on CSR began with Bowen who published "Social Responsibility of the Business Man" in 1953 [5]. Subsequently many researchers during the 60s have attempted to formalize or, more accurately, state what CSR means. Simply, corporate social responsibility means the responsibility or obligation of the firms or organization toward the society for society's and environment benefits or like something. The European Commission has previously defined Corporate Social Responsibility (CSR) as "a concept whereby companies integrate social and environmental concerns in their business operations and in their interaction with their stakeholders on a voluntary basis". CSR's goal is work for the society and environment. Niall Fitzerald, Former CEO, Unilever has defined "Corporate social responsibility is a hard-edged business decision. Not because it is a nice thing to do or because people are forcing us to do it, because it is good for our business". CSR is definitely costly activities for the business firm but it also brings long term sustainability for the firm and its target is to bring corporate image to the firm. As a result, increased consciousness with regards to sustainability issues for financial institutions has been observed across the globe during the last decade. Banks across the globe have received the considerable amount of pressure from its diverse stakeholders including shareholders, investors, media, NGOs and customers to carry out business in a responsible and ethical manner. It is a good sign for the country that now the banking sector of Bangladesh is engaged in various social businesses [8]. Now a day CSR is one of the most crucial subject matters for the financial organizations. The financial organizations like banks, leasing companies, insurance companies especially the private commercial bank try to maintain the CSR. Trotta et al. in a conceptual paper; "Banking Reputation and CSR: a stakeholder value approach" pointed out that, CSR is an important reputational driver, able to create economic value over time. The authors found in their study that there is relationship between CSR and corporate reputation [6]. Similarly a World Bank (2002) described CSR as the businesses' obligations to provide renewable economic development through cooperation with employees, their families, the local community and society in a manner that enhances their livelihood and consequently leads to beneficial business and development [7]. Now the Corporate Social Responsibility is a global concern but it is a matter of sorrow that though it is observed widely internationally but Bangladesh is lagging behind comparing to developed countries of the world. Sustainable development is not possible without the help of corporate world. The author found and showed the importance of the involvement of CSR. Banks enjoy some benefits by engaging CSR activities include improve image, effective risk management, enhanced employee performance and retention. Lind et el introduced tests Concerning Proportions where number of successes and the number of observations, so the proportion of success in a fixed number of trials thus a sample proportion number of successes divided by number of observations.. To test a hypothesis about a population proportion, a random sample is chosen from the population. It is assumed that the assumptions sample data collected are the result of counts, results are mutually exclusive such as yes or no. Independents trials and the probability of success is same for each trials.

\section{Methodology}

\subsection{Sources of Data \\ Primary Data}

A structured (open end) questionnaire was designed to investigate the level of users understanding and their perception towards CSR. The sample of the study covers the banking employees from ten selected private commercial banks in Bangladesh. Sample size was 400 respondents' opinion were collected from top ten private commercial banks' forty clients' and employee's opinion for each banks.

\section{Secondary Data}

Banks' websites, periodicals, Bangladesh Bank's publications, newspapers are used as the secondary sources of the study. A list of related articles from various journals is also used to develop the basic idea about the particular topic and several international efforts and initiatives for developing and implementing CSR standards and guidelines were examined.

\subsection{Data Analysis \\ Hypothesis Testing}

Data are analyzed through hypothesis testing including Ztest. After reviewing the literature the researchers have identified the following hypotheses.

Hypothesis 01=CSR is a tool to gain competitive advantages.

Hypothesis 02=CSR may influence the employees' behavior positively.

Hypothesis 03=CSR has a significant role in establishing a corporate image. 
Hypothesis 04=CSR may influence the customers' behavior positively.

Hypothesis 05=CSR may influence the financial performance.

Hypothesis 06=CSR may be practice enough under regulation of the central bank.

The Hypotheses of the study were formulated in terms of null hypothesis and alternative hypothesis. The data got from the questionnaire had responses supporting either H0 (null hypotheses) or H1 (alternative hypotheses). The researchers have also decided to use Z-test, because, the sample size is more than 30 . The calculating formula of $Z$ is

$Z=\underline{\mathbf{p}-\pi}$

and the level of significance for the test is $5 \%$. This makes the tabulated $\mathrm{Z}$ to be \pm 1.96 .

Also no of observation is 400 and success $x$ (support for the null hypothesis - No) by the respondent's opinion given on each table. $\mathrm{P}=\mathrm{X} / \mathrm{n}, \pi$ is population proportion is $20 \%$,

$\mathbf{D}=\sqrt{ } \pi(1-\pi) \div \mathrm{n}$

\section{ANALYSIS AND FINDINGS}

\subsection{Descriptive Analysis}

The respondents' were asked to give their opinion regarding the level of importance of some important sectors of CSR practices. For descriptive analysis, the researchers considered the mean and standard deviation of the sectors of CSR practices. On the basis of respondents significant opinion following table and graph are designed.

Table 1: Sector wise Patterns of CSR

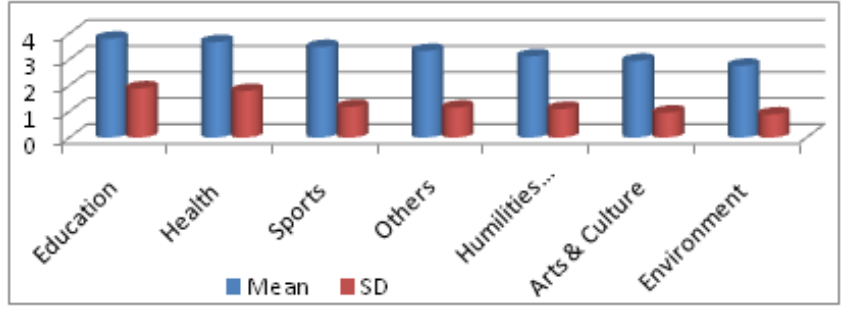

\begin{tabular}{|c|c|c|c|}
\hline & Sector wise Patterns of CSR & Mean & SD \\
\hline 1. & Education & 3.80 & 1.89 \\
\hline 2. & Health & 3.67 & 1.79 \\
\hline 3. & Sports & 3.48 & 1.18 \\
\hline 4. & Others & 3.33 & 1.15 \\
\hline 5. & Humiliates and disaster relies & 3.12 & 1.10 \\
\hline 6. & Arts \& Culture & 2.95 & 0.96 \\
\hline 7. & Environment & 2.76 & 0.89 \\
\hline
\end{tabular}

From the above table and graph indicate that the private commercial banks have given the more concentrations in the sector of education followed by healthcare, sports, Humiliates \& disaster relief and others. The CSR initiatives has proved that the respondents opinion is accurate because in 2011 the sector wise pattern of CSR expenditure BDT (million) private commercial banks in Bangladesh is given below with a chart.

Figure 2: Sector wise Patterns of CSR Expenditure BDT (million)

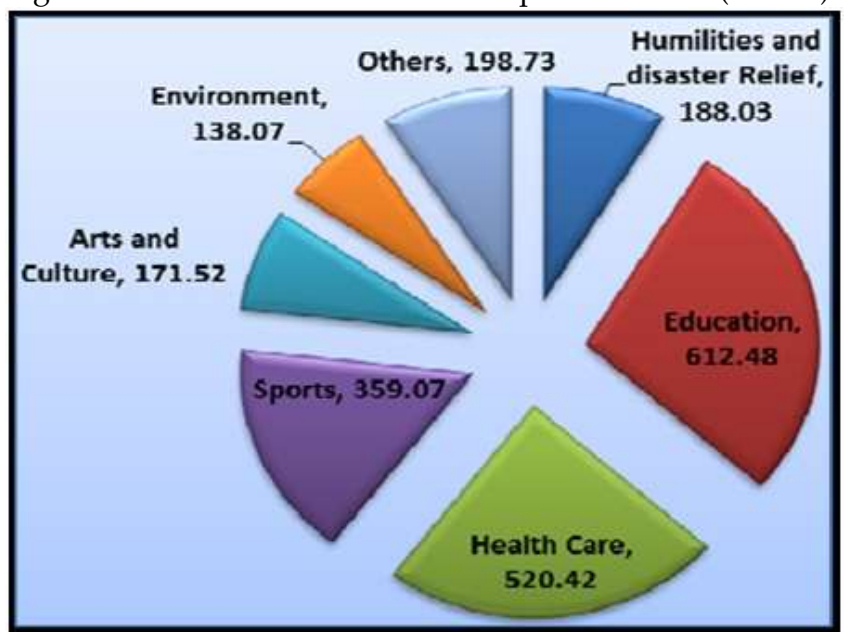

(Source: "Review of CSR initiative of banks; Bangladesh Bank 2011)

In the year 2011, the 'Education' and 'Health Care' sectors were getting more attention and appeared to be the most popular sectors for CSR activities as huge investments are being made by several banks in these segments. Besides these two important sectors large concentrations are found in the field of sports, humanities and disaster relief. As earlier the researchers mentioned, the banks are spending in CSR purpose is increasing gradually. The following table has proved the statement.

Table 2: CSR Expenditures by Banks (Annual)

\begin{tabular}{|c|c|c|c|c|}
\hline & & & & \\
\hline Year & 2008 & 2009 & 2010 & 2011 \\
\hline BDT(Million) & 410.7 & 553.8 & 2329.8 & 2188.33 \\
\hline
\end{tabular}

(Source: "Review of CSR initiative of banks; Bangladesh Bank 2011)

Corporate Social Responsibility (CSR) is a form of corporate self-regulation integrated into a business model. The goal of CSR is to embrace responsibility for the company's actions and encourage a positive impact through its activities on the environment, consumers, stakeholders, communities, public and employees as well. CSR activities of banks broadened substantially in last three years. As of December 2011 all 47 banks have adopted CSR as mainstream extending direct expenditure of total BDT 2188.33 million which is fourfold larger than in 2008 (BDT 410.7 million).

CSR Practices by the Ten Selected Private Commercial Banks The banking sector of Bangladesh has a long history of involvement in benevolent activities like donations to different charitable organizations, to poor people and religious institutions, city beautification and patronizing art \& culture, etc. Recent trends of these engagements indicate that banks are gradually organizing these 76 | P a g e 
Asian Business Review, Volume 2, Number 2/2013 (Issue 5)

ISSN 2304-2613 (Print); ISSN 2305-8730 (Online)

involvements in more structured CSR initiative. The researchers have selected ten special areas of CSR practices and made a comparison between the banks on

the basis of respondents' significant opinion. For such comparison, the researchers assumed the selected areas of CSR to be $100 \%$ and it is shown in the next page.

Table 3: Comparison of Selected Private Commercial Banks of Bangladesh

\begin{tabular}{|c|c|c|c|c|c|c|c|c|c|c|}
\hline $\begin{array}{l}\text { Name of the } \\
\text { banks }\end{array}$ & IBB & Trus & SE BL & City & $\mathrm{NCC}$ & FSBL & PBL & DBBL & NBL & EXIM \\
\hline $\begin{array}{l}\text { B eautific ation } \\
\text { of the city }\end{array}$ & 0 & 1 & 0 & 1 & 0 & 1 & 0 & 1 & 0 & 1 \\
\hline $\begin{array}{l}\text { E ducation of } \\
\text { rootless } \\
\text { children }\end{array}$ & 1 & 1 & 1 & 1 & 1 & 1 & 1 & 1 & 1 & 1 \\
\hline $\begin{array}{l}\text { Accommodation } \\
\text { for slum } \\
\text { dwellers }\end{array}$ & 1 & 0 & 0 & 0 & 0 & 0 & 0 & 1 & 0 & 0 \\
\hline $\begin{array}{l}\text { Publicity } \\
\text { related } \\
\text { women's right } \\
\text { \& anti dowry } \\
\text { practices }\end{array}$ & 1 & 0 & 0 & 0 & 0 & 1 & 0 & 1 & 1 & 0 \\
\hline $\begin{array}{l}\text { Feeding \& } \\
\text { Clothing \& } \\
\text { rehabilitation of } \\
\text { rootless } \\
\text { children }\end{array}$ & 0 & 0 & 0 & 0 & 0 & 1 & 0 & 1 & 0 & 1 \\
\hline $\begin{array}{l}\text { Grants to } \\
\text { organizations in } \\
\text { treating cleft- } \\
\text { lips }\end{array}$ & 0 & 1 & 0 & 1 & 1 & 1 & 1 & 1 & 0 & 0 \\
\hline $\begin{array}{l}\text { Grant } \\
\text { organization } \\
\text { engaged } \\
\text { treating } \\
\text { victims }\end{array}$ & 0 & 1 & 0 & 0 & 0 & 0 & 0 & 1 & 0 & 0 \\
\hline $\begin{array}{l}\text { Technical and } \\
\text { vocational } \\
\text { training to } \\
\text { labor for export } \\
\text { of HR }\end{array}$ & 0 & 0 & 0 & 0 & 0 & 0 & 0 & 0 & 0 & 0 \\
\hline $\begin{array}{l}\text { Infrastructure } \\
\text { of Sports and } \\
\text { training at } \\
\text { national lev el }\end{array}$ & 0 & 1 & 1 & 0 & 1 & 1 & 0 & 1 & 1 & 1 \\
\hline $\begin{array}{l}\text { Providing relief } \\
\text { during various } \\
\text { natural disaster }\end{array}$ & 1 & 1 & 1 & 1 & 1 & 1 & 1 & 1 & 1 & 1 \\
\hline $100 \%$ & 40 & 60 & 30 & 40 & 40 & 70 & 30 & 90 & 40 & 40 \\
\hline
\end{tabular}

Here, 1 means Yes and 0 means No measured as $10 \%$ and $00 \%$.

From the above table, it is clear that DBBL (Dutch Bangla Bank Ltd), covers the more areas than the other private commercial banks and its percentage is $90 \%$ out of $100 \%$. It also indicates, DBBL practices CSR in diversified areas of the society. The FSIBL, Trust bank and EXIM bank have also a good contribution to CSR and deal with different areas of CSR. The rest of the private commercial banks have also contribution to CSR which is less than $50 \%$.

This makes a clear picture that the banks are not concerned with all the areas of CSR including technical and vocational training to labor for export of $H R$, accommodation for slum dwellers and feeding \& clothing \& rehabilitation of rootless children. They are very concerned only about three or four areas. Although, most of the banks are giving more priority on education, sports and natural digester, there are many important areas which should also be considered.

The review of CSR initiative of banks (2011) has mentioned the top five private commercial banks of Bangladesh on the basis of the contribution of CSR which is shown in the following chart. 
Figure 3: Top Five Private Commercial Banks

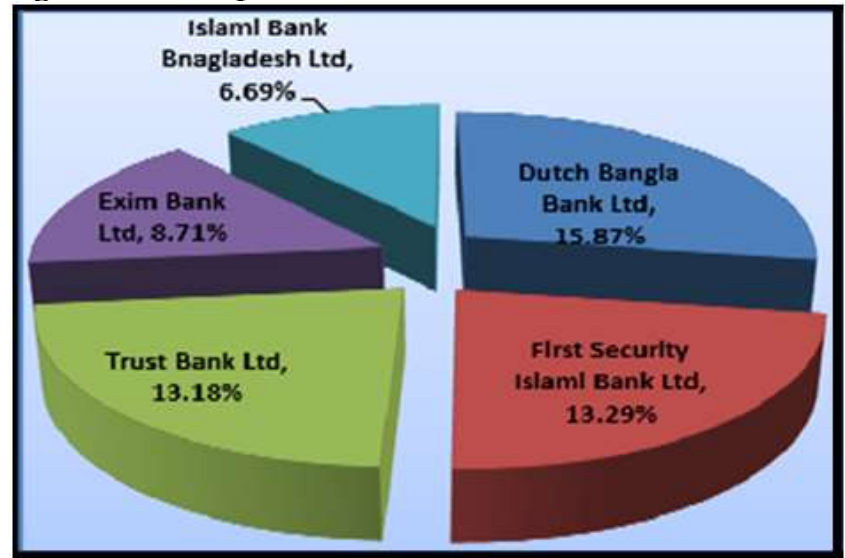

(Source: "Review of CSR initiative of banks; Bangladesh Bank 2011)

This figure also proves that the respondents' opinion is accurate because if the table analyzed the top five banks DBBL (90\%), FSIBL (70\%), Trust bank Ltd (60\%), EXIM $(50 \%)$ and IBBL $(40 \%)$ are same which has mentioned by CSR initiative of Bangladesh Bank, 2011.

\subsection{Hypotheses Testing}

Hypothesis one

"Whether CSR is a tool to gain competitive advantages" $\mathrm{H}_{0}=\mathrm{CSR}$ is not a tool to gain competitive advantages. $\mathrm{H}_{1}=\mathrm{CSR}$ is a tool to gain competitive advantages.

Table 4: Opinion of The respondents on Competitive Advantage of CSR

\begin{tabular}{|c|c|c|}
\hline Responses & No of Responses & Percentage (\%) \\
\hline Yes & 368 & $92 \%$ \\
\hline No & 32 & $8 \%$ \\
\hline Total data collected & 400 & $100 \%$ \\
\hline
\end{tabular}

(Source: Survey conducted on the research)

The calculated value of $Z$ is $|-6|$ and is $|-1.96|$ (Using the formula). Here, calculated value is greater than the table value. So, it can reject the null hypotheses and accept the alternative hypotheses, CSR is tool to gain competitive advantage.

\section{Hypothesis Two}

"Whether CSR may influence the employees' behavior positively"

$\mathrm{H}_{0}=\mathrm{CSR}$ may not influence the employees' behavior positively.

$\mathrm{H}_{1}=$ CSR may influence the employees' behavior positively. Table 5: Opinion of The respondents on employee's behavior

\begin{tabular}{|c|c|c|}
\hline Responses & No of Responses & Percentage (\%) \\
\hline Yes & 375 & $94 \%$ \\
\hline No & 25 & $6 \%$ \\
\hline Total data collected & 400 & $100 \%$ \\
\hline
\end{tabular}

(Source: Survey conducted on the research)

The calculated value of $Z$ is $|-7|$ and is $|-1.96|$ (Using the formula). Here, calculated value is greater than the table value. So, it can reject the null hypotheses and Copyright (C) 2013, Asian Business Consortium | ABR accept the alternative hypotheses, CSR may influence the employees' behavior positively.

Hypothesis Three

"Whether CSR has a significant role in establishing a bank's image"

$\mathrm{H}_{0}=\mathrm{CSR}$ has no significant role in establishing a bank's image. $\mathrm{H}_{1}=$ CSR has a significant role in establishing a bank's image.

Table 6: Opinion of The respondents on Creating Bank's image

\begin{tabular}{|c|c|c|}
\hline Responses & No of Responses & Percentage (\%) \\
\hline Yes & 380 & $95 \%$ \\
\hline No & 20 & $5 \%$ \\
\hline Total data collected & 400 & $100 \%$ \\
\hline
\end{tabular}

(Source: Survey conducted on the research)

The calculated value of $Z$ is $|-7.5|$ and is $|-1.96|$ (Using the formula). Here, calculated value is greater than the table value. So, it can reject the null hypotheses and accept the alternative hypotheses, CSR has a significant role in establishing a bank's image.

\section{Hypothesis Four}

"Whether CSR may influence the customer's behavior positively"

$\mathrm{H}_{0}=$ CSR may not influence the customer's' behavior positively.

$\mathrm{H}_{1}=$ CSR may influence the customer's' behavior positively. Table 7: Opinion of The respondents on Customer's behavior

\begin{tabular}{|c|c|c|}
\hline Responses & No of Responses & Percentage (\%) \\
\hline Yes & 387 & $97 \%$ \\
\hline No & 13 & $3 \%$ \\
\hline Total data collected & 400 & $100 \%$ \\
\hline
\end{tabular}

(Source: Survey conducted on the research)

The calculated value of $Z$ is $|-8.5|$ and is $|-1.96|$ (Using the formula). Here, calculated value is greater than the table value. So, it can reject the null hypotheses and accept the alternative hypotheses, CSR may influence the customer's' behavior positively.

\section{Hypothesis Five}

"Whether CSR may influence the financial performance" $\mathrm{H}_{0}=\mathrm{CSR}$ may not influence the financial performance. $\mathrm{H}_{1}=\mathrm{CSR}$ may influence the financial performance.

Table 7: Opinion of The respondents on financial performance of Bank

\begin{tabular}{|c|c|c|}
\hline Responses & No of Responses & Percentage (\%) \\
\hline Yes & 360 & $90 \%$ \\
\hline No & 40 & $10 \%$ \\
\hline Total data collected & 400 & $100 \%$ \\
\hline
\end{tabular}

(Source: Survey conducted on the research)

The calculated value of $Z$ is $|-5|$ and is $|-1.96|$ (Using the formula). Here, calculated value is greater than the table value. So, it can reject the null hypotheses and accept the alternative hypotheses, CSR may influence the financial performance. 


\section{Hypothesis Six}

"Whether CSR may be practice enough under regulation of the central bank."

$\mathrm{H}_{0}=\mathrm{CSR}$ may not be practice enough under regulation of the central bank.

$\mathrm{H}_{1}=\mathrm{CSR}$ may be practice enough under regulation of the central bank.

Table 7: Opinion of The respondents on central bank's regulation

\begin{tabular}{|c|c|c|}
\hline Responses & No of Responses & Percentage (\%) \\
\hline Yes & 340 & $85 \%$ \\
\hline No & 40 & $15 \%$ \\
\hline Total data collected & 400 & $100 \%$ \\
\hline
\end{tabular}

(Source: Survey conducted on the research)

The calculated value of $Z$ is $|-2.5|$ and is $|-1.96|$ (Using the formula). Here, calculated value is greater than the table value. So, it can reject the null hypotheses and accept the alternative hypotheses, CSR may be practice enough under regulation of the central bank.

\section{Policy implications and Conclusion}

The study reveals the importance of corporate social responsibility as a tool to gain competitive advantage, has positive impact on employees' behavior, customers' behavior and in establishing a bank's image.

These all may create reputation and long term interest by all the parties related to the bank. On the basis of the perception of the bank employees, the study identified the level of importance of some core areas of CSR performance. Among the selected core seven sectors, the respondents have given more importance on the area 'Education'.

Finally, the study attempted to find out the selected ten private commercial bank's performances of CSR in some selected important areas. In this case Dutch Bangla Bank (DBBL) is one of the top most position and The FSIBL, Trust bank and EXIM bank have also a good contribution to CSR and deal with different areas of CSR. Therefore the most of the private commercial banks fall under the average rate.

They consider only a few areas. The banks should diversify their CSR practices and considered the other important areas of the society, such as women empowerment, Sanitation in rural areas, rural development activities related to the poverty alleviation. This can ensure the overall development of the country. For this reason, the central bank ,Bangladesh Bank monitoring the CSR adoption and performance of banks and also give some directions to the banks and provide some priority areas for CSR practice. According to Bangladesh Bank's instruction PCB's are working for CSR which are mentioned in annual reports. As a result now a day's CSR practice has an upward trend which is less than compared to any other first world countries.

\section{ACKNOWLEDGEMENT}

At the very beginning we want to show our best regards to the Almighty because the Almighty gives us the chance to prepare this report.

During the period of research and survey, we had gained altruistic assistance from number of persons and organizations. Without their assistance it was not possible for us to conduct the research. This work was supported in a part by the Bangladesh Bank (The Central Bank of Bangladesh) and top private commercial banks in Bangladesh which are concerned for CSR activities and for our research purpose we have picked them from all other banks in Bangladesh. All the employees of the banks helped us through providing a lot of their internal information which was made our research uncomplicated and convenient. Finally, we are grateful to Asian Business Review (ABR) where we are finally going to send our research paper for the publication. They also helped us a lot through providing a template where all the techniques and steps are given with examples of a sophisticated research paper and some information like submission process, editing process, etc.

\section{REFERENCES}

[1] Abdul Kaium Masud, 2011, CSR practices of private commercial bank's in Bangladesh: A comparative study, MPRA Paper No. 35496

[2] A. A. Abbaas, \& A.I. Ibrahim. 2012, ,International Journal of Business and Management, Corporate Social Responsibility and Employee Engagement in Jordan, Vol. 7, on.16, ISSN 1833-3850 E-ISSN 1833-8119

[3] European Commission, 25.10.2011, Communication from the commission to the European parliament, the council, the European economic and social committee and the regions.

[4] Bhattacharya et al., 2004; Ogrizek, 2001; Frenz , 2005; Jeucken, 2001; 2004; Coupland, 2005.

[5] Almona, C. P. 2005, 'A Review of The Business Case for Corporate Social Responsibility in the UK Financial Services Sector, A dissertation presented in part consideration for the degree of MBA in Corporate Social Responsibility'.

[6] Trotta, A., A., Iannuzzi, G., Cavallaro \& S., Dell'atti, 'Banking reputation and CSR: a stakeholder value approach'. Available: http:/ /www.google.com

[7] World bank. 2002, 'Corporate social responsibility and sustainable competitiveness'. Retrieved from http:/ / www.worldbank.org/wbi/copgov /csr/index.htm

[8] Edi. I.I. and I.I., Etu 2011,'CSR activities of banking industry in Bangladesh'. Financial Express, Bangladesh.

[9] Niall Fitzerald, "Quotations from Business and Thought Leaders on Ethics and CSR". Retrieved from http://www.interpraxis.com/quotes.htm

Douglas A. lind, William G. Marchal \& Samuel A.Wathen. Statistical Techniques in Business and Economics. McGraw-Hill/Irwin. Pp.349-352, 2010 